\title{
China clay workers in the south west of England: analysis of chest radiograph readings, ventilatory capacity, and respiratory symptoms in relation to type and duration of occupation
}

\author{
C J OGLE, E M RUNDLE, E T SUGAR \\ From ECC International Ltd, St Austell, Cornwall PL25 4DJ, UK
}

\begin{abstract}
In 1985, employees in the china clay industry were offered chest $x$ ray examinations and 4478 (52.6\% of the total workforce) accepted. Of these, 4167 workers and pensioners of the largest single employer also completed occupational histories, respiratory symptom questionnaires, and underwent ventilatory capacity tests. The $x$ ray readings (read to the 1980 ILO classification) of the 4167 workers and pensioners were analysed to seek relations between the indices of pulmonary health and occupational exposure. The information available, particularly on occupational history, was more detailed than in previous studies of 1961, 1977, and 1981. Analyses show that in the improved operating conditions of recent years the average worker exposed to dust only after 1971 would not expect to develop category 1 pneumoconiosis through a full working life in any of the industry's occupations. For those with exposure before 1971 the category reached will depend on the amount of early exposure, but the rate of development of pneumoconiosis since 1971 is about half that before 1971. The milling of china stone, a practice that ceased over 15 years ago in the china clay industry, had by far the largest effect on $x$ ray category, whereas of the current occupations, employment in china clay attritor mills has the greatest effect. Ventilatory capacity is related to $x$ ray category as well as age, and results for loss of ventilatory capacity in relation to age, $x$ ray category, and smoking habits were similar to the results in previous studies. Respiratory symptoms are associated with smoking class and a loss in ventilatory capacity $\left(\mathrm{FVC}\right.$ or $\left.\mathrm{FEV}_{1}\right), \mathrm{FEV}_{1}$ being the most dominant. Allowing for this, there was no further effect for years of exposure, $x$ ray category, or age.
\end{abstract}

In 1985 a chest $x$ ray survey was carried out by the Nottingham based mobile unit of the National Coal Board using $40 \times 40 \mathrm{~cm}$ films. It was offered to all people employed in the china clay industry in the south west of England. The subsequent analyses were based on a group of workers from the largest single employer, which represented $94 \%$ of the china clay industry for which full occupational details were available. For this group an overall response rate of $65 \%$ was achieved. For china clay employees in potentially dusty occupations (where measured respirable dust concentrations may exceed 0.5 $\mathrm{mg} / \mathrm{m}^{3}$ ), however, the response rate was higher, at approximately $85 \%$.

Accepted 21 March 1988
Earlier chest $x$ ray surveys of china clay workers were carried out in $1961,{ }^{1} 1977,{ }^{2}$ and 1981 . The 1961 examination was offered to people producing and handling dry china clay. The 1977 examination was offered to all employed in potentially dusty occupations. The 1981 and the present surveys were open to all in the industry. Each $x$ ray survey included questionnaires on occupational history and, with the exception of 1961, recorded ventilatory capacity, respiratory symptoms, and smoking habits. Participation in each survey was on a voluntary basis.

The aim of the study was to monitor the effect of working environment on pulmonary health and in particular to decide whether the progressive improvements in the working environment over the years had decreased the extent of pneumoconiosis. 


\section{Data}

The data available for analysis were epidemiological $x$ ray readings, occupational histories, lung function measurements, and a respiratory symptoms questionnaire including detailed history of smoking habits. Many dust concentration measurements for specific jobs and locations have also been collected and used indirectly in the analyses.

\section{DUST CONCENTRATIONS}

In the winning and processing of china clay the amount of respirable dust likely to be produced varies from a low level where the clay is being processed as a dilute slurry to a higher level when the clay is being dried or milled. ${ }^{34}$ For the purpose of this analysis, employment was categorised into groups with similar dust exposure levels. Dust measurements of a rudimentary nature had been carried out since 1965 but only since 1978 had personal respirable and total dust measurements been made. It is not possible to quantify with any accuracy dust concentrations before 1978.

Dust concentrations are now measured using either MRDE 113A gravimetric samplers or personal sampling pumps fitted with the Casella/MRC cyclone heads. Job groupings were based on average dust concentrations at various production locations since systematic sampling began.

Many operational changes have been introduced, mainly in the 1970 s, to improve airborne dust control and to reduce the amount generated in the production process. The many changes have led to a progressive reduction in airborne dust concentrations.

Table 1 shows the average respirable dust concentration measurements and the numbers of samples taken for the different types of production locations at which sampling is carried out from January 1984 to March 1986.

Since the effect of china clay dust on the lung is expected to be cumulative and long term, and there are as yet inadequate data to provide a reliable exposure index for individual subjects, it was necessary to use

Table 1 Average measurements of personal respirable dust by location January 1984-March 1986

\begin{tabular}{lll}
\hline Location type & No of samples & Average dust $\left(\mathrm{mg} / \mathrm{m}^{3}\right)$ \\
\hline Dryers & 681 & 1.9 \\
Attritor mills & 114 & $2 \cdot 7$ \\
Calciners & 63 & $2 \cdot 5$ \\
Slurry plants* & 69 & $1 \cdot 1$ \\
Tube presses & 5 & 0.5 \\
\hline
\end{tabular}

*This is an assumed average figure based on regular sampling at the older of the two slurry plants, known to be more dusty, and a small number of samples at the modern, less dusty plant.
Table 21985 radiographic response by current occupation

\begin{tabular}{llll}
\hline & $\begin{array}{l}\text { No } \\
\text { eligible }\end{array}$ & $\begin{array}{l}\text { No } \\
\text { x rayed }\end{array}$ & $\begin{array}{l}\% \\
\text { Response }\end{array}$ \\
\hline $\begin{array}{l}\text { China clay: } \\
\begin{array}{l}\text { Dry processing (dryers, } \\
\text { attritor mills, slurry } \\
\text { plants, tube presses) }\end{array}\end{array}$ & 825 & 697 & 85 \\
$\begin{array}{l}\text { Calciners } \\
\text { Wet processing (pits, } \\
\text { refining plants) }\end{array}$ & 129 & 110 & 85 \\
$\begin{array}{l}\text { Services and office jobs } \\
\text { Total no of china clay } \\
\text { employees (as at 1 May }\end{array}$ & 945 & 580 & 61 \\
$\begin{array}{l}\text { 1985) } \\
\text { China clay pensioners (as at } \\
\quad \text { May 1985) }\end{array}$ & 2189 & 2444 & 61 \\
$\begin{array}{l}\text { Total No examined } \\
\text { radiographically }\end{array}$ & & 3831 & 65 \\
\hline
\end{tabular}

the duration of service in various occupations in these analyses.

\section{RESPONSE TO SUR VEY}

The proportion of those examined by radiography to those eligible averaged $85 \%$ for current china clay employees in potentially dusty jobs. The breakdown of response for the survey as a whole according to occupation is shown in table 2 . The response by age for those aged between 25 and 65 was fairly uniform at about $80 \%$; for employees under 25 the response was $61 \%$.

Table 2 shows that the response from pensioners was only $15 \%$. Of the responding pensioners, $61 \%$ finished their employment in potentially dusty occupations (see below) compared with $33 \%$ for the total of responding and non-responding pensioners, which may indicate that the responding pensioners were biased towards those with dust exposure.

For current employees the proportion of all eligible employees with potentially dusty occupations was $16 \%$, whereas the percentage of responders in potentially dusty occupations was $21 \%$. Therefore responding current employees were also biased towards those with dust exposure.

\section{RAY READINGS}

The $x$ ray films of the 4167 workers and pensioners who took part in the survey were read "blindly" and independently by a panel of three experienced readers. The readings were read to the standard ILO classification of radiographs of pneumoconioses, revised 1980.5

\section{OCCUPATIONAL HISTORY}

In previous surveys occupational history questionnaires were completed at the time of the $x$ ray examination. The different types of employment were categorised into a limited fixed set of groups. This 
restricted any further separation of the job groups in the subsequent analyses.

For this survey a voluntary occupational history questionnaire was sent to each employee and pensioner some months in advance, seeking a detailed occupational history from the date of leaving school. This was in the expectation that a more detailed and precise job history would be obtained. In the event only about $70 \%$ of those examined by radiography completed the questionnaire. Where completed questionnaires were not returned by the participants, occupational histories were compiled from existing records.

The completed questionnaires were coded using alpha-numeric codes for the jobs and locations within the china clay industry (over 200 different employee jobs and 700 distinct locations were recognised; however, not all jobs exist at each location). For employment before joining the china clay industry a numeric code was assigned, indicating whether or not the job entailed exposure to dusts with an attendant risk of pneumoconiosis.

A system is now being implemented to update occupational histories on a regular basis. The information is being coded using the same categories used for the questionnaires.

\section{EXCLUSIONS}

Based on the above occupational history questionnaire and other factors the following people were excluded from the analyses.

(1) five men whose films were designated as quality 4 (unreadable) by two or more readers.

(2) Two hundred and thirteen women.

(3) Eight pensioners who were aged over 80.

(4) Nine men who did not take the ventilatory capacity tests.

(5) The 243 men whose occupational history showed them to have been exposed to dust before joining the china clay industry.*

This left 3400 workers and 289 pensioners to be included in the analyses. Although the proportion of responding pensioners was low, their inclusion provided valuable information on jobs that no longer exist in the industry and the effects of long term exposure.

\section{NON-DUSTY LIFE}

Previous studies used age and durations of service in the various job groups as separate independent variables in the analysis of the data. The problem with this approach is that the age of a person is clearly related to

\footnotetext{
*These include 73 men in hard rock mining and quarrying, 64 in coal mining and handling, 55 in carbonate or ball clay work, 26 in china stone, 11 in asbestos, and 14 others.
}

Table 3 Job classification used in analyses

\begin{tabular}{lll}
\hline Job classifications & Before 1971 & After 1971 \\
\hline Non-dusty life & Y & Y \\
Dryers & Y & Y \\
Pan kilns & Y & NA \\
Slurry plants and tube presses & NA & Y \\
Calciners & Y & Y \\
China stone & Y & NA \\
Attritor mills & Y & Y \\
\hline
\end{tabular}

$\mathrm{Y}=$ Job exists.

the period he holds a job and this reduces the reliability of the mathematical analyses. In this study the duration of "non-dusty life" has also been used as one of the independent variables in some analyses. The term non-dusty life is defined as the sum of the time before employment, the time after retirement, and time in jobs where the level of respirable dust does not exceed that of the normal living conditions of the general population (typically less than $0.3 \mathrm{mg} / \mathrm{m}^{3}$ ). In the present study working life spent in offices, workshops, vehicles, and pits has been included in non-dusty life.

\section{JOB GROUPINGS USED IN ANALYSES}

For the purpose of analysis it was decided to make a distinction between "early" and "late" dust exposure, by choosing 1971 ( 1 January) as the dividing date. It was around this date that the older drying processes (pan kilns) were phased out. The grinding and flotation of china stone also ended at the start of the 1970s.

Table 3 shows the job classifications used in the analyses where "Y" indicates that a job exists and NA indicates that it is inapplicable.

The job classifications other than non-dusty life are referred to below as potentially dusty jobs.

Table 4 Distribution of $1985 x$ ray readings of small opacities

\begin{tabular}{|c|c|c|c|c|c|c|c|}
\hline \multirow[b]{2}{*}{ Category } & \multicolumn{3}{|c|}{ Reader } & \multirow[b]{2}{*}{ Median } & \multirow[b]{2}{*}{$\%$} & \multirow[b]{2}{*}{ Total } & \multirow[b]{2}{*}{$\%$} \\
\hline & $I$ & 2 & 3 & & & & \\
\hline Unreadable & 0 & 4 & 5 & 0 & 0 & 9 & 0.08 \\
\hline $\begin{array}{l}0 /- \\
0 / 0 \\
0 / 1\end{array}$ & $\begin{array}{r}70 \\
3056 \\
272\end{array}$ & $\begin{array}{r}143 \\
2991 \\
227\end{array}$ & $\begin{array}{r}208 \\
2791 \\
225\end{array}$ & $\begin{array}{r}98 \\
3058 \\
218\end{array}$ & $\begin{array}{r}2.66 \\
82.90 \\
5.91\end{array}$ & $\begin{array}{r}421 \\
8838 \\
724\end{array}$ & $\begin{array}{r}3.80 \\
79.86 \\
6.54\end{array}$ \\
\hline $\begin{array}{l}1 / 0 \\
1 / 1 \\
1 / 2\end{array}$ & $\begin{array}{r}119 \\
122 \\
11\end{array}$ & $\begin{array}{r}97 \\
138 \\
30\end{array}$ & $\begin{array}{r}139 \\
220 \\
33\end{array}$ & $\begin{array}{r}113 \\
134 \\
24\end{array}$ & $\begin{array}{l}3.06 \\
3.63 \\
0.65\end{array}$ & $\begin{array}{r}355 \\
480 \\
74\end{array}$ & $\begin{array}{l}3 \cdot 21 \\
4 \cdot 34 \\
0 \cdot 67\end{array}$ \\
\hline $\begin{array}{l}2 / 1 \\
2 / 2 \\
2 / 3\end{array}$ & $\begin{array}{r}9 \\
22 \\
3\end{array}$ & $\begin{array}{r}15 \\
35 \\
4\end{array}$ & $\begin{array}{r}14 \\
45 \\
4\end{array}$ & $\begin{array}{r}7 \\
31 \\
1\end{array}$ & $\begin{array}{l}0.19 \\
0.84 \\
0.03\end{array}$ & $\begin{array}{r}38 \\
102 \\
11\end{array}$ & $\begin{array}{l}0.34 \\
0.92 \\
0.10\end{array}$ \\
\hline $\begin{array}{l}3 / 2 \\
3 / 3 \\
3 /+\end{array}$ & $\begin{array}{l}2 \\
3 \\
0\end{array}$ & $\begin{array}{l}1 \\
4 \\
0\end{array}$ & $\begin{array}{l}1 \\
4 \\
0\end{array}$ & $\begin{array}{l}1 \\
4 \\
0\end{array}$ & $\begin{array}{l}0.03 \\
0.11 \\
0.00\end{array}$ & $\begin{array}{r}4 \\
11 \\
0\end{array}$ & $\begin{array}{l}0.04 \\
0.10 \\
0.00\end{array}$ \\
\hline Total & 3689 & 3689 & 3689 & 3689 & 100 & 11067 & 100 \\
\hline
\end{tabular}


Table 5 Distribution of $x$ ray category by age

\begin{tabular}{lcrrrr}
\hline & \multicolumn{5}{c}{ No in category } \\
\cline { 3 - 6 } Age & Total No & 0 & 1 & 2 & 3 \\
\hline 520 & 28 & 28 & 0 & 0 & 0 \\
$21-30$ & 730 & 724 & 6 & 0 & 0 \\
$31-40$ & 889 & 854 & 35 & 0 & 0 \\
$41-50$ & 854 & 781 & 61 & 12 & 0 \\
$51-60$ & 817 & 700 & 101 & 13 & 3 \\
$61-70$ & 291 & 227 & 53 & 11 & 0 \\
$71-80$ & 80 & 60 & 15 & 3 & 2 \\
Total & 3689 & 3374 & 271 & 39 & 5 \\
\hline
\end{tabular}

VENTILATORY CAPACITY

A Vitalograph spirometer was used to measure vital capacity (FVC) and forced expiratory volume in one second $\left(\mathrm{FEV}_{1}\right)$. Each subject was allowed five attempts and in the analyses the average of the best three results were used as recommended by Oldham and Cole. ${ }^{6}$

\section{RESPIRATORY SYMPTOMS}

Each participant was asked a series of questions by an experienced clerk in order to complete a respiratory symptoms questionnaire at the time of the $x$ ray examination. This was based on the MRC 1976 questionnaire and was more comprehensive than those used in earlier industry studies. Its main aim was to establish the prevalence of cough, phlegm, breathlessness, wheezing, and previous chest related illnesses and injuries together with past and present smoking habits. Of the 3689 people considered in this survey, 1146 were non-smokers, 1061 were ex-smokers, and 1482 were smokers.

\section{Analysis and results}

\section{CHEST RADIOGRAPHS}

\section{Large opacities}

Of the 3689 films examined, 16 were found by two or more readers to show the presence of large opacities and in 10 of these cases the presence of other diseases was also recorded. The remaining six cases occurred among older men (average age 62) with an average of 20 years employment in potentially dusty jobs, except for one man who had been employed in jobs with little or no dust (incorporated in non-dusty life). The median reading of small opacities (see below) for these six men was category 2 in four cases and category 1 in the other two.

\section{Pleural changes}

Pleural thickening was recorded by one or more readers in 87 films and of these, 47 were noted by more than one reader. The number of cases recorded in exsmokers (28) is significantly greater than in smokers (10) and in non-smokers (9).
The written comments recorded by readers when reading the $x$ ray films were examined. In 41 of the 47 radiographs readers had recorded signs of other diseases, possible asbestos exposure, or rib abnormalities.

Pleural thickening was treated as a yes/no variable and subjected to binary regression analysis. The results indicate that the likelihood of occurrence of pleural thickening increases with age and $x$ ray category (profusion of small opacities, see below) and is dependent on smoking class. There was no dependence on years of employment in potentially dusty jobs.

Seventeen cases of pleural calcification were recorded, 12 of them by more than one reader. In 14 cases other diseases or injury were also noted and there were possibilities of asbestos exposure in the remaining three cases.

\section{Small opacities}

Profusion Table 4 shows the number of films in each category read by each reader with the median reading. Table 5 gives a breakdown by age of major $x$ ray category of the median reading. It should be noted that 10 of the 39 films read at category 2 and three of the five films read at category 3 were of pensioners (though the proportion of pensioners in the study population was only $8 \%$ ).

Small opacity zones Where opacities were present they were more often recorded in the lower and middle zones than in the upper zones of the lung (on average $19 \%$ of recorded opacities were in the upper zones of the lung compared with $39 \%$ in the middle and $42 \%$ in the lower). For non-smokers slightly more opacities occurred in the middle zones than in the upper zones, whereas for smokers and ex-smokers the reverse was true.

Shape and size of small opacities The small opacities were most often recorded as being a mixture of rounded and irregular shapes of medium size. Overall, $60 \%$ of small opacities were recorded as being pure or predominantly rounded in shape. Significantly more smokers and ex-smokers were recorded as having predominantly or pure irregular opacities than non-smokers. Table 6 shows percentages of each

Table 6 Shapes of small opacities separated by smoking class (\%)

\begin{tabular}{lllll}
\hline & $\begin{array}{l}\text { Non- } \\
\text { smokers }\end{array}$ & $\begin{array}{l}\text { Ex- } \\
\text { smokers }\end{array}$ & Smokers & $\begin{array}{l}\text { Whole } \\
\text { population }\end{array}$ \\
\hline Pure, rounded & 35 & 27 & 26 & 28 \\
Predominantly rounded & 31 & 31 & 33 & 32 \\
Predominantly irregular & 24 & 26 & 24 & 24 \\
Pure, irregular & 10 & 16 & 17 & 16 \\
\hline
\end{tabular}


smoking class in each of the summarised shape groupings.

\section{INTRAOBSER VER VARIATION}

The conformity of readings between the three readers was good with only 255 films $(4 \cdot 8 \%)$ giving results wider than three subcategories and 38 films $(0 \cdot 7 \%)$ wider than four subcategories. On individual inspection, it was shown that for the films for which the interpretations between readers differed by more than three subcategories, there was a far higher incidence of incorrectly exposed films (60\% compared with $32 \%$ overall) and also a higher incidence of other disease noticed by one or more of the readers. In fact, twice as many comments per film were made by the readers for the films showing divergent readings, compared with the overall level. (Up to three of the free format comments made by each reader when reading the films were recorded for analysis.)

\section{CONVERSION OF X RAY CATEGORY TO \\ NUMERICAL SCORE}

Oldham postulated that, given experienced readers, most of the disagreement between their readings depends on variation in their judgment as to where films lie on the continuum of profusion in relation to the boundaries between subcategories. ${ }^{7}$ From this he deduces that some average of the readers' readings will correspond more closely to the true position of the film on the continuum than will the choice of one of the readings as correct. He derived a method of averaging which leads to a numerical score, taking account of the apparent widths of the subcategories (which may vary between readers) and approximating to a continuous variable. The major category 0 then corresponds to a score of less than 1, major category 1 corresponds to a score of more than 1 but less than 2 , etc. This procedure was applied to the present readings, even those showing wide disagreement, so giving a numerical score for every film.
REGRESSION ANALYSIS OF X RAY CATEGORY Following the procedure of Oldham, ${ }^{2}$ the natural logarithm of the numerical $x$ ray score as the dependent variable was regressed against duration of employment in the grouped job categories and in nondusty life.

In exploratory analyses, separate regressions were carried out for smokers, ex-smokers, and nonsmokers. The results of each were so similar that the three groups were recombined into a single group. Similarly analyses carried out, including and excluding pensioners, showed no significant difference. The inclusion, however, of pensioners improved the reliability of the statistical models and gave an insight into jobs that no longer exist within the industry together with the effects of long term exposure. Therefore pensioners were included in the analyses below.

In the main data set there were 3689 subjects. To separate the effect of recent operating conditions, a further analysis was carried out which excluded the 764 subjects, who were in potentially dusty jobs before 1971 - that is, who were employed in dryers, attritor mills, pan kilns, china stone, or calciners at any time before 1971. Thus the data set for this analysis contained 2925 subjects including those in jobs before 1971 with little or no dust (incoporated in non-dusty life) and those recruited on or after 1 January 1971 regardless of their job.

\section{REGRESSION COEFFICIENTS}

Table 7 shows the regression coefficients and standard errors for the two analyses. The number of subjects in each category is given.

Of the current job classifications, the regression coefficients show that employment in mills has the greatest effect on $x$ ray category, followed by dryers. This is in keeping with the average respirable dust concentrations (table 1). Employment in calciners has a low effect despite the relatively high dust concentra-

Table 7 Regression coefficients of $1000 \times$ Loge $_{e}$ (radiological score) on years of exposure

\begin{tabular}{|c|c|c|c|c|c|c|}
\hline \multirow[b]{2}{*}{ Job classification } & \multicolumn{3}{|l|}{ All employees } & \multicolumn{3}{|c|}{ Employees with little or no dust pre-1971 } \\
\hline & No of subjects & Regression coefficient & Std error & No of subjects & Regression coefficient & Std error \\
\hline \multirow{3}{*}{$\begin{array}{l}\text { Non-dusty life } \\
\text { Dryers: } \\
\text { Pre-1971 } \\
\text { Post-1971 }\end{array}$} & 3689 & 6 & 0.4 & 2925 & 6 & 0.4 \\
\hline & 522 & 25 & 2 & & & \\
\hline & 997 & 14 & 1 & 519 & 10 & 2 \\
\hline & 325 & 8 & 1 & 255 & 7 & 1 \\
\hline \multicolumn{6}{|l|}{ Calciners: } & \\
\hline Post-1971 & 202 & 10 & 3 & 135 & 5 & 3 \\
\hline Pan kilns & 248 & 13 & 2 & & & \\
\hline \multicolumn{7}{|l|}{ Attritor mills: } \\
\hline $\begin{array}{l}\text { Pre-1971 } \\
\text { Post-1971 }\end{array}$ & 138 & 44 & 4 & & & \\
\hline Post-1971 & 73 & 23 & 4 & 16 & 12 & 11 \\
\hline
\end{tabular}


tions (this was also found by Oldham ${ }^{2}$ ). The reason for this is not known but the calcined material no longer has the crystalline structure and form of kaolin.

For attritor mills and dryers the regression coefficients are significantly lower for post-1971 employment than for the corresponding pre-1971 employment, being about half in the first analysis and a third in the analysis excluding those with exposure before 1971. This is indicative of the effect of improved working conditions.

Few subjects were employed in calciners before 1971 and this job classification was insignificant in the regression.

In china stone mills there were again few subjects but the incidence of pneumoconiosis was high ( 14 of 37 people had a radiological score of 1 or more) and this occupation had by far the highest regression coefficient. This contrasts with the findings of Oldham ${ }^{2}$ and Rossiter (unpublished), in whose studies the china stone mills were found to be comparable with dryers and attritor mills in their effect. This is almost certainly because of the detailed occupational histories available in the present study, allowing for the clear identification of those exposed to china stone dust, and shows the importance of such information. In addition there may be a progressive effect of china stone dust in the lung. (The composition of china stone differs from china clay. China stone can contain up to $25 \%$ quartz whereas china clay contains less than $1 \%$.)

For the total population, $24 \%$ of the variance was accounted for by occupational history. In the population of 3689 only $8.5 \%$ had an $x$ ray category greater than major category 0 and $43 \%$ had had potentially dusty jobs whereas in the $1977 x$ ray survey ${ }^{2}$ which concentrated mainly on workers in china clay dryers there were $23 \%$ above major category 0 and almost $100 \%$ with some employment in a potentially dusty job. This may account for the slightly higher level of explained variance found by Oldham $(32 \%$ as opposed to $24 \%)^{2}$

In the population with little or no exposure before 1971 (the second of the analyses) the variance accounted for was lower, at $9 \%$. This was due to a lower proportion having been exposed to clay dust $(28 \%)$ but more particularly to a lower proportion of abnormal films ( $4 \%$ above category 0 ).

A detailed analysis of the post-1971 group showed that of the 123 subjects whose $x$ ray score was greater than 0 , only 24 had at any time worked in potentially dusty jobs as defined previously, 48 had worked only in jobs judged to have no dust, and the remaining 51 had worked in jobs judged to have little exposure to dust (refining plants and pits). Of the $x$ ray films for the 123 subjects, 102 were found by two or more readers to

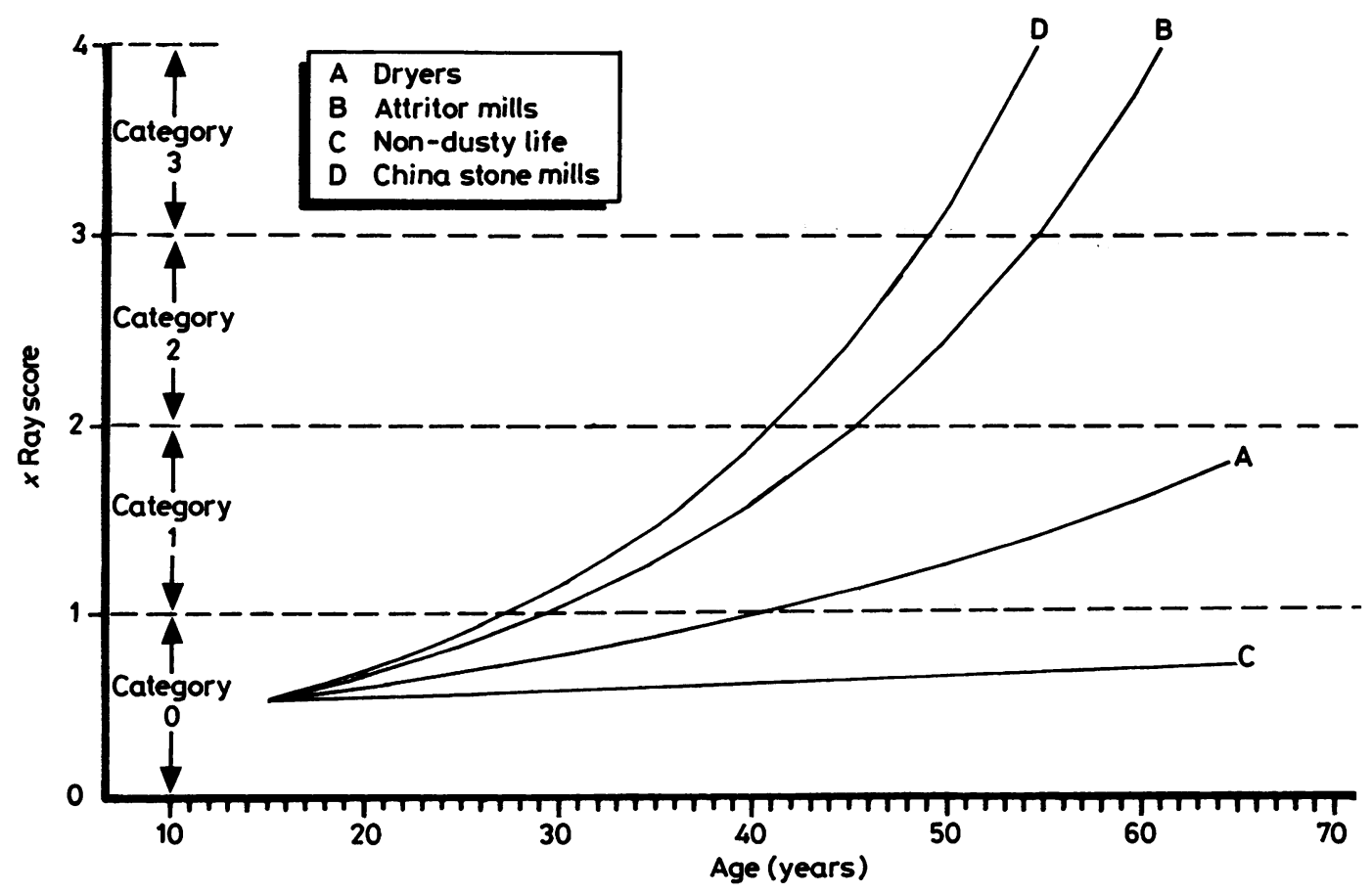

Fig 1 Predicted radiological score for continuous employment in pre-1971 conditions. 


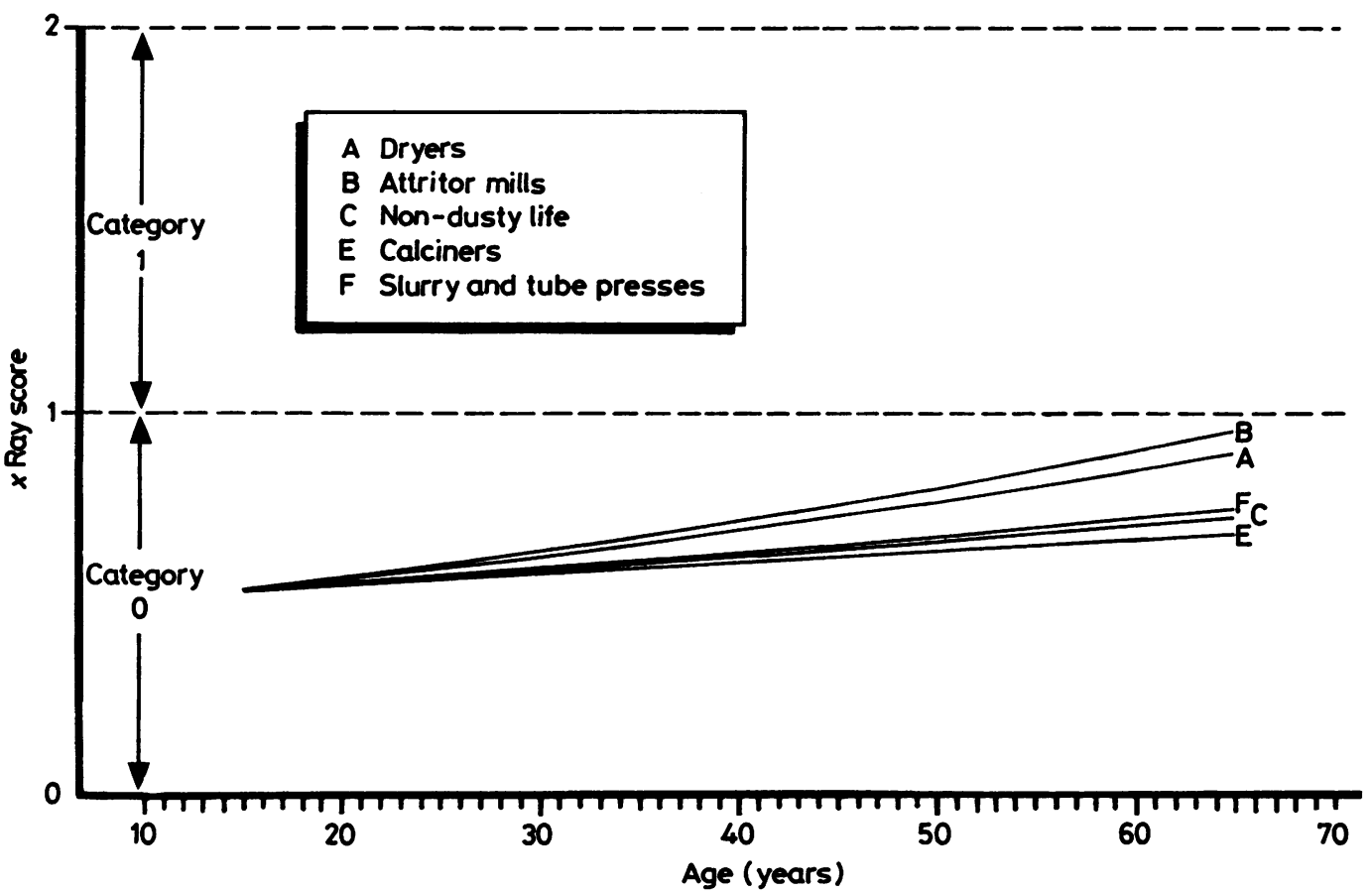

Fig 2 Predicted radiological score for continuous employment in post-1971 conditions.

be of poor quality or to show signs of disease other than pneumoconiosis, as was also the case for 17 of the 24 subjects who had worked in potentially dusty jobs. A further point relevant to this group of subjects is that they are generally older than the total population, with $61 \%$ being over 50 (compared with $34 \%$ in the study population). To investigate further the abnormal readings in this group, a small subset of films of category 1 have been reread clinically and the findings will be discussed in a subsequent publication.

\section{AGE AND X RAY SCORE IN DIFFERENT JOBS}

The data have been presented in a graphical form based on the average man following a single job classification from the start of employment at age 15 . Figure 1 shows predicted radiological score versus age for this average man who joined before 1971 and worked for example in a dryer (line $A$ ) as it then was. It is implicit in the analysis that the working conditions did not change, or are averaged, although in reality conditions have improved. Examples are also given in the figure for the average man working in an attritor mill (line B), in the grinding of china stone (line D), and in a non-dusty occupation (line $C$ ). The lines are calculated by the formula:

$$
\begin{aligned}
\log _{e}(\text { score at age } p)= & \text { Intercept } \\
& +15 \times \text { coefficient for non- } \\
& \text { dusty life } \\
& +(p-15) \times \text { coefficient for } \\
& \text { job group }
\end{aligned}
$$

Figure 2 shows the predicted radiological score for continuous employment in post-1971 conditionsthat is, for those with no potentially dusty jobs before 1971. The lines therefore show what would be expected

\begin{tabular}{|c|c|c|c|c|c|c|}
\hline & \multicolumn{2}{|l|}{ Non-smokers } & \multicolumn{2}{|l|}{ Ex-smokers } & \multicolumn{2}{|l|}{ Smokers } \\
\hline & Regression coefficient & Std error & Regression coefficient & Std error & Regression coefficient & Std error \\
\hline $\begin{array}{l}\text { Age } \\
\text { Radiological score }\end{array}$ & $\begin{array}{r}-36 \\
-235\end{array}$ & $\begin{array}{r}2 \\
74\end{array}$ & $\begin{array}{r}-50 \\
-250\end{array}$ & $\begin{array}{r}2 \\
65\end{array}$ & $\begin{array}{r}-45 \\
-256\end{array}$ & $\begin{array}{r}1 \\
62\end{array}$ \\
\hline
\end{tabular}
to happen to the average man in the future, employed in each of the jobs, but in conditions as they have averaged since 1971 .

Table 8 Regression coefficients of FVC in $\mathrm{ml}$ (adjusted for height) on age and radiological score 
Table 9 Regression coefficients of $F E V_{1}$ in $m l$ (adjusted for height) on age and radiological score

\begin{tabular}{|c|c|c|c|c|c|c|}
\hline & \multicolumn{2}{|l|}{ Non-smokers } & \multicolumn{2}{|l|}{ Ex-smokers } & \multicolumn{2}{|l|}{ Smokers } \\
\hline & Regression coefficient & Std error & Regression coefficient & Std error & Regression coefficient & Std error \\
\hline $\begin{array}{l}\text { Age } \\
\text { Radiological score }\end{array}$ & $\begin{array}{r}-37 \\
-217\end{array}$ & $\begin{array}{r}1 \\
63\end{array}$ & $\begin{array}{r}-48 \\
-142\end{array}$ & $\begin{array}{r}2 \\
60\end{array}$ & $\begin{array}{r}-46 \\
-165\end{array}$ & $\begin{array}{r}1 \\
56\end{array}$ \\
\hline
\end{tabular}

The imprecision in the estimated effect of exposure is hard to specify. It will depend more on the validity of the dose response relation assumed than on statistical errors and will become clearer as further surveys are carried out in 1990 and 1995.

\section{VENTILATORY CAPACITY}

Of the five spirometry readings of FVC and $\mathrm{FEV}_{1}$ the average of the three best (independent) readings was used in analysis. These values were normalised for height of $1.7 \mathrm{~m}^{8}$ as follows:

and

$$
\mathrm{FVC}_{\text {normalised }}=\mathrm{FVC}_{\text {measured }} \times 1.7^{2} \times \mathrm{H}^{-2}
$$

$$
\mathrm{FEV}_{1 \text { normalised }}=\mathrm{FEV}_{1 \text { measured }} \times 1.7^{2} \times \mathrm{H}^{-2}
$$

where $\mathrm{H}$ is the height of the individual in metres.

No correction was applied for varying body weight.

\section{REGRESSION ANALYSIS OF VENTILATORY}

CAPAGITY

The two ventilatory capacity measurements (FVC and
$\mathrm{FEV}_{1}$ ) were regressed against age, radiological score, and years of exposure in the various job groupings. Because ventilatory capacity has previously been found to be related to smoking history, the analyses were carried out separately for the three smoking classes (non-smokers, ex-smokers, and current smokers). Differences in the intensity or pattern of smoking and changes in past smoking habits have not been considered.

The effect of employment history on ventilatory capacity is unclear, with few occupations having a statistically significant effect and the pattern differing across the smoking classes. In fact some occupations gave an apparent improvement to ventilatory capacity. The variance accounted for in the analyses ranged from $36 \%$ to $49 \%$. In all cases by removal of occupational exposures as dependent variables the variance accounted for declined by at most $1 \%$. Therefore a fair interpretation of the results is that ventilatory capacity is related to age and radiological score and it is not necessary to incorporate

\begin{tabular}{|c|c|c|c|c|}
\hline Symptom/definition & Non-smokers & Ex-smokers & Smokers & All classes \\
\hline $\begin{array}{l}\text { Cough: } \\
\text { Usual cough during winter }\end{array}$ & 7 & 13 & 18 & 13 \\
\hline $\begin{array}{l}\text { Cough } 3 \text { months: } \\
\text { Cough most days for as much as } 3 \text { months each year }\end{array}$ & 2 & 6 & 9 & 6 \\
\hline $\begin{array}{l}\text { Phlegm: } \\
\text { Usually bring up phlegm during winter }\end{array}$ & 11 & 17 & 21 & 17 \\
\hline $\begin{array}{l}\text { Phlegm } 3 \text { months: } \\
\text { Phlegm most days for as much as } 3 \text { months each year }\end{array}$ & 4 & 8 & 10 & 7 \\
\hline $\begin{array}{l}\text { Cough \& phlegm: } \\
1 \text { occurrence of increased cough and phlegm lasting for } 3 \text { weeks or } \\
\text { more over past } 3 \text { years }\end{array}$ & 6 & 9 & 9 & 8 \\
\hline $\begin{array}{l}\text { Cough \& phlegm }+ \text { : } \\
\text { More than } 1 \text { occurrence of cough } \& \text { phlegm }\end{array}$ & 2 & 4 & 4 & 3 \\
\hline $\begin{array}{l}\text { Breathless grade 1: } \\
\text { Troubled by shortness of breath hurrying on level ground or walking } \\
\text { up slight hill }\end{array}$ & 7 & 18 & 15 & 14 \\
\hline $\begin{array}{l}\text { Breathless grade } 2 \text { : } \\
\text { Short of breath walking with people of own age on level ground }\end{array}$ & 2 & 5 & 3 & 3 \\
\hline $\begin{array}{l}\text { Breathless grade } 3 \text { : } \\
\text { Stop for breath when walking at own pace on level ground }\end{array}$ & 1 & 2 & 1 & 1 \\
\hline $\begin{array}{l}\text { Chest wheeze: } \\
\text { Chest sometimes sounds wheezing or whistling }\end{array}$ & 10 & 19 & 29 & 20 \\
\hline $\begin{array}{l}\text { Chest wheeze }+: \\
\text { Chest wheezes or whistles on most days }\end{array}$ & 1 & 4 & 5 & 3 \\
\hline $\begin{array}{l}\text { Chest illness: } \\
1 \text { chest illness lasting for one week or more in past } 3 \text { years }\end{array}$ & 7 & 10 & 8 & 8 \\
\hline $\begin{array}{l}\text { Chest illness }+: \\
\text { More than } 1 \text { chest illness }\end{array}$ & 1 & 4 & 3 & 3 \\
\hline $\begin{array}{l}\text { Asthma: } \\
\text { Has or has had asthma }\end{array}$ & 6 & 7 & 4 & 5 \\
\hline
\end{tabular}

Table 10 Percentage of employees with positive answers to respiratory symptom questions 
Table 11 Numbers of cases of cough and phlegm by age group, exposure group, and major x-ray category. Observed numbers and numbers predicted solely from level of FEV

\begin{tabular}{|c|c|c|c|c|c|c|c|c|}
\hline Age (y) & Obs & Pred & Exposure & Obs & Pred & $x$ Ray & Obs & Pred \\
\hline $\begin{array}{l}15- \\
20- \\
30- \\
40- \\
50- \\
60- \\
70-\end{array}$ & $\begin{array}{r}0 \\
40 \\
66 \\
58 \\
67 \\
46 \\
22\end{array}$ & $\begin{array}{r}0.41 \\
37.26 \\
53.52 \\
64 \cdot 71 \\
84.82 \\
42.41 \\
15.90\end{array}$ & $\begin{array}{l}0 \\
1- \\
10- \\
20- \\
30- \\
40-\end{array}$ & $\begin{array}{r}168 \\
55 \\
46 \\
19 \\
11 \\
0\end{array}$ & $\begin{array}{r}166.93 \\
54.58 \\
42.10 \\
24.22 \\
9.94 \\
1.26\end{array}$ & $\begin{array}{l}0 \\
1 \\
2 \\
3\end{array}$ & $\begin{array}{r}264 \\
28 \\
6 \\
1\end{array}$ & $\begin{array}{r}265.63 \\
28.35 \\
4.49 \\
0.56\end{array}$ \\
\hline All ages & 299 & 299.03 & All exposures & 299 & 299.03 & All categories & 299 & 299.03 \\
\hline
\end{tabular}

occupational history to explain changes in ventilatory capacity. This result was also obtained by Oldham. ${ }^{2}$ Tables 8 and 9 show the resulting regression coefficients using age and radiological score as independent variables.

For all smoking classes, ventilatory capacity is highly dependent on age. Both FVC and FEV 1.0 decline more rapidly for ex-smokers and smokers than for non-smokers.

Ventilatory capacity is also dependent on radiological score. An increase of $x$ ray score by one (equivalent to a change of one major $x$ ray category) may be equated to 6.5 years of aging for non-smokers in its effect on FVC, and to 5.0 and 5.7 years of aging for ex-smokers and smokers respectively.

\section{RESPIRATORY SYMPTOMS}

Table 10 summarises the positive responses to the respiratory questionnaire and gives details of the symptoms analysed.

There are 3682 people included in this and subsequent symptom analyses. Seven did not complete a questionnaire.

\section{BINARY REGRESSION ANALYSIS OF RESPIRATORY SYMPTOMS}

The potential effect of all the data collected on the probability of exhibiting respiratory symptoms was investigated using binary regression analysis separately for the three smoking classes. For the first level of symptom the most dominant effect was the level of ventilatory capacity, and indeed if FEV was $_{1}$ allowed for then there was no further effect for years of exposure, $x$ ray category, or even age on the probability of a symptom. This finding has been confirmed by comparing the numbers of cases of a symptom by age, exposure, and $x$ ray category with the numbers predicted solely from the level of $F E V_{1}$. This is illustrated in table 11 for the symptom cough and phlegm (for all smoking classes combined) and shows that FEV 1 predicts cough and phlegm excellently irrespective of age, $x$ ray category, or years of exposure. The discrepancies show no clear pattern except that the number of cases aged $30-40$ is consistently underestimated and the number aged 50-60 consistently overestimated.

The results of the above analysis also show that the smoking classes differ. Smokers show a higher probability of exhibiting a symptom at a particular $\mathrm{FEV}_{1}$ than non-smokers. For ex-smokers there is no such constant relation; for the symptom of cough exsmokers are similar to non-smokers, whereas for phlegm and cough and phlegm they have a similar level of symptoms as non-smokers at high FEV, but at

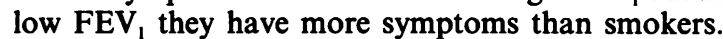
Figure 3 shows the predicted level of cough and phlegm for the three smoking classes. The higher level(s) of each symptom had too few positive responses for any satisfactory conclusions to be drawn.

\section{Conclusions}

Several major conclusions emerge from this 1985 study. In general, the effect of employment in current occupations on $x$ ray category is greatest for attritor mill workers. For some jobs, notably dryers and attritor mills, the occupations have carried less attendant risk of pneumoconiosis since the early 1970 s when dust control was improved. Under these improved conditions the average person exposed to dust only after 1971 would not be expected to reach category 1 in a full working life. For those with exposure before 1971, the category reached will depend on the extent of the early exposure, but the rate of development of pneumoconiosis in conditions after 1971 is approximately halved.

The milling of china stone has the largest effect on $x$ ray category, and higher than in previous studies. This occupation ceased completely within the industry some 15 years ago. There is some evidence that the effect of exposure to china stone dust may be progressive.

The perceived personal effect of pneumocionosis is the associated loss of ventilatory capacity rather than 


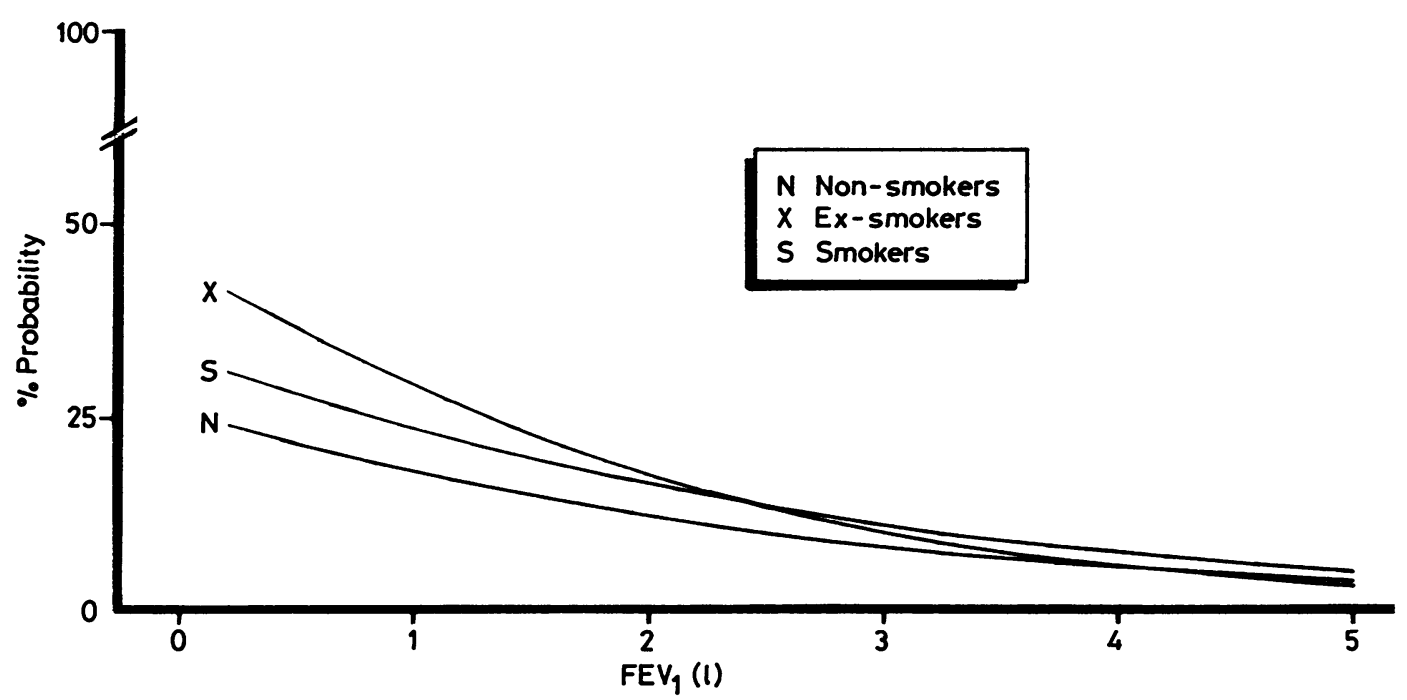

Fig 3 Probability of exhibiting cough and phlegm.

the $x$ ray category itself. The results, as in previous studies, showed that vital capacity declines with age (and more rapidly for smokers) and with $x$ ray category, and that a change of one major category is equivalent to five to six years of aging. FEV also declines with age (and again more for smokers) at about the same rate as vital capacity. FEV is also dependent on $x$ ray category. Relating these results to the expected changes in $x$ ray category implies that a full working life under the worst current conditions could lead to a loss in ventilatory capacity equivalent to five to six years of aging.

A further finding in this study is that the probability of exhibiting respiratory symptoms can be explained by the level of ventilatory capacity alone for each of the three smoking classes. Age, exposure to dust, and $x$ ray category have no additional effect.

We gratefully acknowledge the great and continuing help from Professor P D Oldham in the conversion of $x$ ray categories to numerical scores, the interpretation of the analyses, and advice on the statistical methods used. We also thank Dr J C Gilson and Dr G Sheers for their many helpful and constructive comments and gratefully acknowledge the useful early discussions, encouragement, and reviews of the manuscript by Dr W B Jepson and the help of R A Comyns and Dr J H Sewart.

\section{References}

1 Sheers G. Prevalence of pneumocionosis in Cornish kaolin workers. Br J Ind Med 1964;21:218-25.

2 Oldham PD. Pneumoconiosis in Cornish china clay workers. $\mathrm{Br} J$ Ind Med 1983;40:131-7.

3 Menadue KJ. Developments in the china clay industry in Cornwall. Transactions of the Institute of Mining and Metallurgy 1979;88:A43-50.

4 Pemberton MJ. The processing of china clays. Royal Society of Chemistry's Industrial Chemistry Bulletin 1983;2:183-7.

5 International Labour Office. Guidelines for the use of international classification of radiographs of pneumoconiosis. Geneva: ILO, 1980. (Occupational safety and health series No 22 (rev).)

6 Oldham PD, Cole TJ. Estimation of the FEV 1.0. Thorax 1983;38:662-7.

7 Oldham PD. Numerical scoring of radiological pneumoconiosis. In: Walton WH, ed Inhaled particles III. London: Unwin; 1971:621-30.

8 Cole TJ. Linear and proportional regression models in the prediction of ventilatory function. Journal of the Royal Statistical Society series A 1975;138:297-338. 